https://doi.org/10.15407/scine17.02.064

BELIKOV, K.M.' (https://orcid.org/0000-0002-1682-6064),

BRYLEVA, E.Yu.' (https://orcid.org/0000-0002-8903-4922),

BUNINA, Z.Yu.' (https://orcid.org/0000-0002-8639-958X),

VARCHENKO, V.V.' ${ }^{1}$ (https://orcid.org/0000-0002-7369-1637),

ANDRYUSHCHENKO, A.Yu.' (https://orcid.org/0000-0001-6256-2568),

SHCHERBAKOV, I.B.-H.' (https://orcid.org/0000-0002-9450-2153),

KALCHENKO, V.I. ${ }^{2}$ (https://orcid.org/0000-0002-0325-7544),

DRAPAILO, A.B. ${ }^{2}$ (https://orcid.org/0000-0002-8701-1380),

ZONTOV, A.V. ${ }^{3}$ (https://orcid.org/0000-0003-0520-5833),

and ZONTOVA, L.V. ${ }^{3}$ (https://orcid.org/0000-0002-3361-2535),

'Institute for Single Crystals, the NAS of Ukraine,

60 , Nauky Ave., Kharkiv, 61072, Ukraine,

+380 57341 0357, info@isc.kh.ua

${ }^{2}$ Institute of Organic Chemistry, the NAS of Ukraine,

5, Murmanska St., Kyiv, 02660, Ukraine,

+380442927150, ioch@ioch.kiev.ua

3 Smoly State Enterprise,

179, M. Anoshkina St., Kamianske, 51917, Ukraine,

+38056958 4523, dpsmoly@gmail.com

\title{
SOLID PHASE EXTRACTANTS FOR ACTINIDE AND LANTHANIDE REMOVAL BASED ON POROUS POLYMERS IMPREGNATED WITH MULTIDENTATE CHELATING LIGANDS
}

Introduction. Treatment and disposal of radioactive wastes as well as monitoring of radioactive isotope content in environmental objects are actual tasks in the developed world. Lanthanide and transuranium element removal from spent nuclear fuel of nuclear power plants allows decreasing waste amount to be dumped and diminishing the risk of environmental pollution by radionuclides.

Problem Statement. Considering extreme radiotoxicity of transuranium elements and tight standards restricting their activity in air and water, there is an urgent need to develop accurate and highly sensitive methods for pollution control.

Purpose. Development of solid phase extractants (SPEs) based on porous polymers impregnated with multidentate chelating ligands for lanthanide, uranium and transuranium element removal from aqueous solutions.

Materials and Methods. The materials used are porous divinylbenzene polymers of POROLAS brand and styrene-divinylbenzene copolymers from Smoly SE (Kamianske); multidentate chelating ligands of actinides and lanthanides such as $N, N, N^{\prime}, N^{\prime}$-tetra-n-octyl-oxapentane-1,5-diamide (TODGA) and carbamoyl phosphine

Citation: Belikov, K. M., Bryleva, E. Yu., Bunina, Z. Yu., Varchenko, V. V., Andryushchenko, A. Yu., Shcherbakov, I. B.-H., Kalchenko, V. I., Drapailo, A. B., Zontov, A. V., and Zontova, L. V. Solid Phase Extractants for Actinide and Lanthanide Removal Based on Porous Polymers Impregnated with Multidentate Chelating Ligands. Sci. innov. 2021. V. 17, no. 2. P. 64-71. https://doi.org/10.15407/scine17.02.064 
oxides (CMPO); sorbent from TrisKem (France) based on TRU Resin (Eichrom Industries, Inc.). The research techniques are inductively coupled plasma atomic emission spectrometry, IR spectroscopy, scanning electron spectroscopy, spectrofluorimetry.

Results. The solid-phase extractants (SPEs) for actinide and lanthanide removal from aqueous solutions have been synthesized by impregnation of porous polymeric POROLAS matrices and TODGA, CMPO-(PhOct) and CMPO-(Ph2). Sorption kinetics has been studied and capacity values for the different sorbents have been estimated. Extractive columns for uranium and europium concentration have been manufactured.

Conclusions. SPEs studied demonstrate a high efficiency in removing uranium and europium from aqueous solutions. Due to their characteristics obtained materials may be used for preconcentration of target ions in radioecologycal monitoring procedures.

Keywords: spe, carbamoyl methyl phosphine oxides, tetraoctyl diglycolamide, and radionuclides.

Actinide and lanthanide radioisotopes contained in spent nuclear fuel of nuclear power plants and in the accidental emissions of Chornobyl and $\mathrm{Fu}$ kushima are toxic and dangerous because of a long half-life and a high mobility in surface soil [1]. Currently, ${ }^{241} \mathrm{Am}$ and isotopes of $\mathrm{U}$ are of particular importance among these radionuclides. ${ }^{241} \mathrm{Am}$ is 100 -fold more toxic than ${ }^{241} \mathrm{Pu}$, and its amount in the environment increases over time as a result of ${ }^{241} \mathrm{Pu}$ decay. The mobility of ${ }^{241} \mathrm{Am}$ is significantly higher than that of plutonium due to a higher solubility. So, americium easily enters animal or human bodies, accumulates in bone tissue and becomes the source of intrinsic radiation [2]. Monitoring of uranium content is also an important task since this element has carcinogenic and mutagenic properties and is a general cellular poison with delayed action on human body.

The most widely used method for ${ }^{241} \mathrm{Am}$ activity determination is $\alpha$-spectrometry that requires a time- and labor-consuming preparation of an emitter [3,4]. Furthermore, in most real cases, there are complex mixtures that contain other $\alpha$-isotopes in addition to americium (uranium, thorium and products of their decay) with activity of these isotopes being significantly higher than the americium activity. Therefore, there is an unmet need for the selective removal of ${ }^{241} \mathrm{Am}$ from matrices in order to both prevent signal overlap with other components and concentrate the radionuclide. Uranium can also be determined by an $\alpha$-spectrometry method with a time-consuming sample preparation; however, an error during such determination can reach 30-60\% [5].
Based on the state of the art, the development of the accurate and highly sensitive methods for monitoring the content of above mentioned radionuclides in natural surface or ground water and other natural objects has attached critical importance.

Currently, application of SPEs, which are materials combining properties of both selective liquid extractants and porous solid sorbents, becomes a promising trend for ecological monitoring. Advantages of the SPEs include a high capacity inherent to liquid extractants and a simple technological process of metal ion removal inherent to sorbents [6]. The most widely used SPE for binding of radionuclides including uranium is a porous styrene and divinylbenzene copolymer impregnated with tributyl phosphate (TBP), a conventional industrial extractant [7]. A disadvantage of the SPE with TBP is the lack of complexing ability and selectivity for uranium and other actinides.

An effective method to enhance selectivity of the SPEs for americium and uranium involves impregnation of porous matrices with multidentate complexing ligands, such as $N, N, N^{\prime}, N^{\prime}$-tetra$n$-octyl-oxapentane-1,5-diamide (TODGA) and carbamoyl phosphine oxides (CMPO), that form

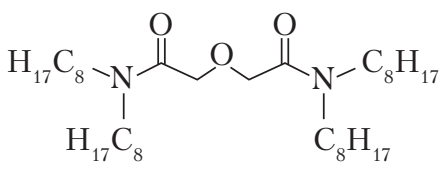

(a)

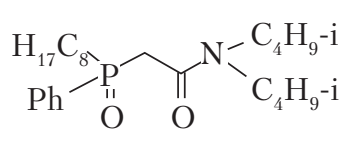

(b)
Fig. 1. Chemical structures of TODGA $(a)$ and CMPO(PhOct) $(b)$ 


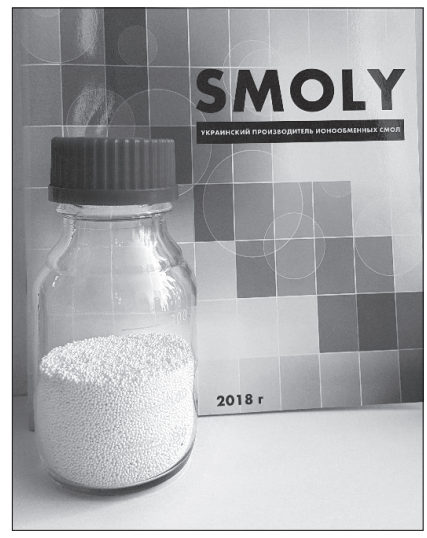

Fig. 2. Illustrative SPE C1103 obtained using the porous styrene-divinylbenzene copolymer from SOE "Smoly"

tight chelates with these radionuclides. Polymeric matrix nature is also essential for SPE quality. The matrix should have a homogeneous extended surface to ensure efficient mass exchange at the organic/water interface and contain spherical particles of uniform size to provide the most advantageous hydrodynamic extraction processes.

In this work, divinylbenzene polymers and styrene-divinylbenzene copolymers from SOE "Smoly" (Kamianske) obtained by free radical bead polymerization were used as the porous matrices. Spherical particle sizes of the porous matrices were in the range of $60-160 \mathrm{~mm}$, an upper limit of the specific surface area was $1000 \mathrm{~m}^{2} / \mathrm{g}$.

Chelating multidentate ligands (Fig. 1), $N, N, N^{\prime}$, $N^{\prime}$-tetra- $n$-octyl-oxapentane-1,5-diamide (TOD$\mathrm{GA})$ and (N,N-diisobutylcarbamoylmethyl)octylphenylphosphine oxide (CMPO-(PhOct)) were synthesized according to published procedures $[8,9]$.

Impregnation of the porous polymers with TODGA and CMPO ligands was performed according to [6].

\section{Sorption materials for americium concentration}

It is to be noted that carrying out sorption experiments with isotope ${ }^{241} \mathrm{Am}$ is quite complicated in usual analytical laboratories. Because americium is a highly toxic element and special equip- ment and licenses are needed to work with open radiation sources, methods for its removal are often developed using europium as a model element with the same chemical properties [10,11]. In this respect, Eu was used in this work for testing sorption properties of the resins modified with TODGA.

Despite the fact that a great variety of TODGAbased sorption materials has been studied, several issues remain to be investigated. Among them are identification of a stable and inexpensive sorbent matrix, effective americium removal in a column mode from solutions containing large amounts of coexisting ions, possibility of column reuse etc.

The list of the SPEs investigated for Eu(III) removal is provided in Table 1 and an illustrative SPE is shown in Fig. 2.

Sorption properties were studied in a wide $\mathrm{pH}$ range: in nitric acid solutions with concentrations

Table 1. SPEs for Eu(III) Ion Removal

\begin{tabular}{|c|c|}
\hline SPE ID & Composition \\
\hline C1099 & $\begin{array}{l}\text { POROLAS-T(1), } 0.063-0.1 \mathrm{~mm}, 60 \% \\
\text { TODGA } 40 \%\end{array}$ \\
\hline C1101 & $\begin{array}{l}\text { POROLAS-T(2), } 0.063-0.1 \mathrm{~mm}, 60 \% \\
\text { TODGA } 40 \%\end{array}$ \\
\hline C1103 & $\begin{array}{l}\text { Styrene-divinylbenzene copolymer, } \\
0.063-0.1 \mathrm{~mm}, 60 \% \\
\text { TODGA } 40 \%\end{array}$ \\
\hline C1115 & $\begin{array}{l}\text { POROLAS-T(1) } 0.063-0.1 \mathrm{~mm}, 56.5 \% \\
\text { TODGA } 32 \% \\
\text { CMPO-(PhOct) } 11.5 \%\end{array}$ \\
\hline C1117 & $\begin{array}{l}\text { TRU Resin (TRISCEM), } 0.1-0.16 \mathrm{~mm} \text {, } \\
60 \% \\
\text { TODGA, } 40 \%\end{array}$ \\
\hline C1141 & $\begin{array}{l}\text { Styrene-divinylbenzene copolymer, } \\
0.1-0.16 \mathrm{~mm}, 60 \% \\
\text { TODGA, } 40 \%\end{array}$ \\
\hline Matrices & \\
\hline POROLAS-T(1) & a nonionic porous sorbent obtained by \\
\hline POROLAS-T(2) & $\begin{array}{l}\text { bead copolymerization of divinylben- } \\
\text { zene and styrene in the presence of a } \\
\text { porogene followed by conditioning to } \\
\text { make its surface more hydrophilic. } \\
\mathrm{T}(1) \text { and } \mathrm{T}(2) \text { differ by porogenes used }\end{array}$ \\
\hline $\begin{array}{l}\text { Styrene-divinyl- } \\
\text { benzene copolymer }\end{array}$ & $\begin{array}{l}\text { a product obtained by bead copoly- } \\
\text { merization of divinylbenzene and sty- } \\
\text { rene using a porogene }\end{array}$ \\
\hline
\end{tabular}


of 0.5 to $6 \mathrm{~mol} / \mathrm{l}$ and with $\mathrm{pH}$ of 1 to 7 (Fig. 3 ). Considering europium hydrolysis, $\mathrm{pH}$ values above 7 were not investigated. The highest removal rate appeared for nitric acid solutions with concentrations above $0.5 \mathrm{~mol} / \mathrm{l}$ [12]. However, it should be noted that the removal rate also increased with increase in $\mathrm{pH}$ from 2 to 7 allowing for the effective use of the sorbents at $\mathrm{pH}$ values of about $6-7$.

The effect of $\mathrm{pH}$ on the removal rate was studied as following. $20 \mathrm{ml}$ of the europium test solution was added to the weighted amount of sorbents $(0.05 \mathrm{~g})$. The concentration of europium in the test solution was $20 \mathrm{mg} / \mathrm{ml}$. Then $\mathrm{pH}$ was measured by a STARTER 3100 pH-meter (OHAUS, USA) and adjusted to a desired value with $\mathrm{HNO}_{3}$ or $\mathrm{NaOH}$. The concentrations of europium in the solutions before and after sorption were measured by inductively coupled plasma atomic emission spectrometry using an iCAP 6300 Duo spectrometer (Thermo Scientific, USA).

Sorption isotherms were obtained using $1 \mathrm{~mol} / 1$ nitric acid solutions containing europium at concentrations ranging from 20 to $300 \mathrm{mg} / \mathrm{l}$. Aliquots $(20 \mathrm{ml})$ of these solutions were transferred to $50 \mathrm{ml}$ conical flasks with pre-weighed sorbents $(0.05 \mathrm{~g})$. Next stages of the experiment were as defined for the $\mathrm{pH}$ effect determination.

Sorption kinetics was investigated by examining the effect of contact time on europium sorption. Aliquots $(20 \mathrm{ml})$ of the europium ion solution with concentration of $20 \mathrm{mg} / \mathrm{l}$ (prepared in $1 \mathrm{~mol} / 1 \mathrm{HNO}_{3}$ solution) were added to pre-weighed sorbents $(0.05 \mathrm{~g})$ in $50 \mathrm{ml}$ conical flasks. The flasks were then shaken at $300 \mathrm{rpm}$ for different amounts of time. After that the sorbents were filtered and europium concentrations before and after sorption were measured using inductively coupled plasma atomic emission spectrometry.

Table 2. Sorption Capacity of the SPEs Studied

\begin{tabular}{|c|c|c|c|c|}
\hline \multicolumn{5}{|c|}{ Sorption capacity, mg/g } \\
\hline C1099 & C1101 & C1103 & C1115 & C1117 \\
10.25 & 11.28 & 25.07 & 9.04 & 22.03 \\
\hline
\end{tabular}

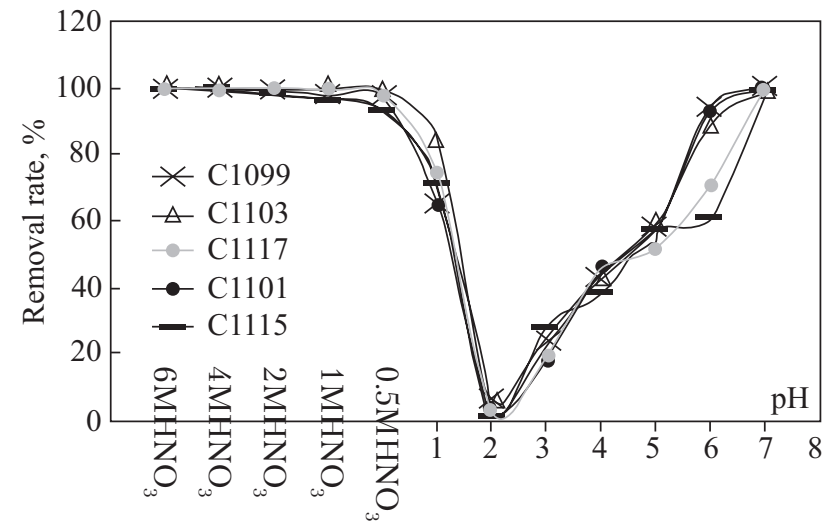

Fig. 3. Removal rate of Eu(III) ions vs. pH in the solution for the different SPEs

Sorption capacity was calculated by an equation:

$$
q=\frac{\left(c_{0}-c_{e}\right) V}{m},
$$

where $c_{0}$ is an initial concentration of $\mathrm{Eu}(\mathrm{III})$ ions, $\mathrm{mg} / \mathrm{l} ; c_{e}$ is a concentration of $\mathrm{Eu}$ (III) ions in the solution after sorption; $V$ is a volume of the solution, $1 ; m$ is a sorbent mass, $g$.

Table 2 shows that the SPE C1103 has the highest sorption capacity, which is even superior to the sorption capacity of the SPE C1117 from TRISKEM. Sorption characteristics of the SPE C1115 containing both TODGA and CMPO are substantially similar to that demonstrated for the

Table 3. SPEs for $\mathbf{U O}_{2}{ }^{2+}$ Removal

\begin{tabular}{|l|l|}
\hline SPE ID & \multicolumn{1}{|c|}{ Composition } \\
\hline C1119 & POROLAS-T(1) \\
& $0.063-0.1 \mathrm{~mm}$ \\
& $28 \%$ TBP \\
C1140 & $12 \%$ CMPO-(PhOct) \\
& Styrene-divinylbenzene copolymer, $0.1-0.16 \mathrm{~mm}$ \\
& $28 \%$ TBP \\
& $12 \%$ CMPO-(PhOct) \\
\hline
\end{tabular}

Table 4. Sorption Capacities of the SPEs for $\mathrm{UO}_{2}{ }^{2+}$ in a $1 \mathrm{M}$ HNO3 Solution

\begin{tabular}{|c|c|}
\hline \multicolumn{2}{|c|}{ Sorption capacity, mg/g } \\
\hline C1119 & C1140 \\
39 & 35 \\
\hline
\end{tabular}




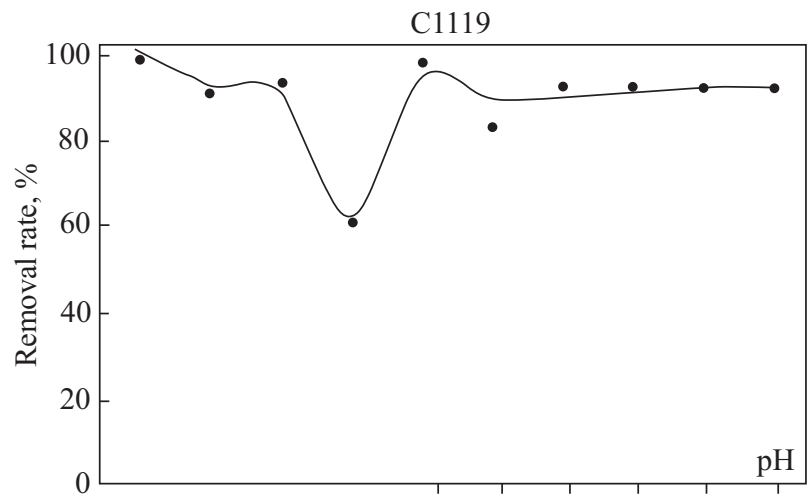

$\mathrm{C} 1140$

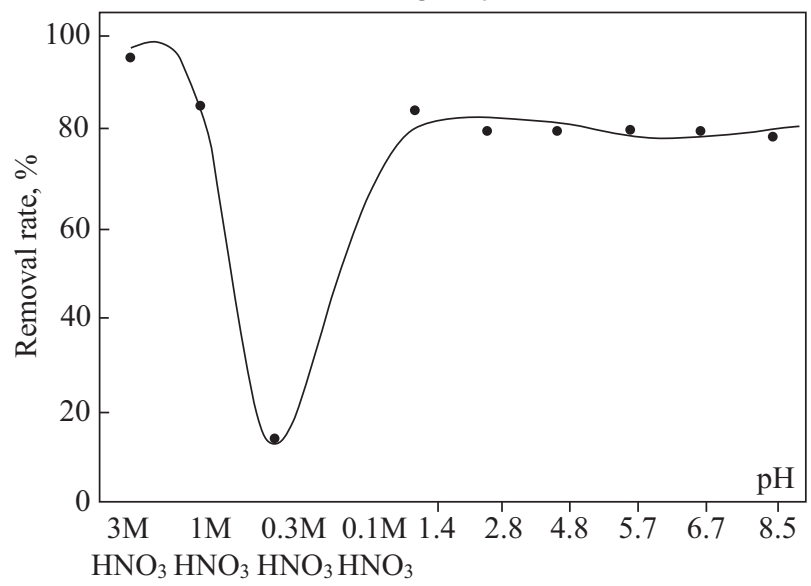

Fig. 4. Removal rate of uranyl ions by the SPEs C1119 and C1140 vs. $\mathrm{pH}$ of the solution

SPE C1099 made up of the same matrix but containing only TODGA.

Sorption kinetics was studied for the SPE with the highest sorption capacity i.e. C1103. In order to investigate the mechanism of the sorption process, several common kinetic models of sorption were tested: the pseudo-first order model, the pseudo-second order model, the Elovich equation, and the Dumwald-Wagner model.

Experimental data were fitted by the nonlinear method of least squares using Origin software according to the models applied. The Dumwald-Wagner model was in the best agreement with the experimental sorption kinetics of Eu(III) ions on the SPE C1103.

Thus, it indicates a chemisorption process, which takes place in three stages:

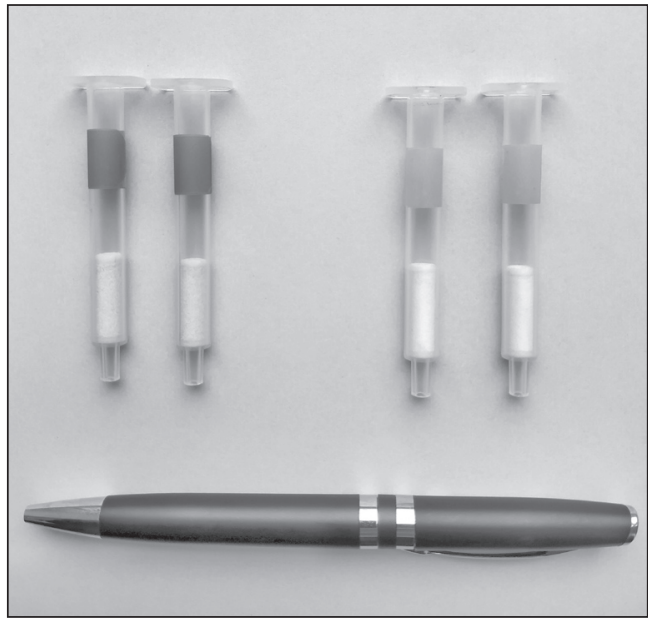

Fig. 5. Extractive columns for europium, americium, and uranium concentration

- the rapid diffusion of the metal ions to the SPE surface and adsorption on it;

- the transfer of the metal ions from the SPE surface in a liquid organic phase of the impregnated ligand and formation of a chelate complex;

- adsorption-desorption at the equilibrium.

\section{Sorption materials} for uranium concentration

Due to high sensitivity (about $10^{-10} \mathrm{~g}$ of $\mathrm{U}$ ), a luminescent method for trace uranium determination is known to be widely used for ore, natural water, and industrial product or waste analyses [13]. Uranyl complexes with inorganic anions are the most promising luminescent agents.

The removal rate of uranium by the SPEs designed was evaluated through determination of residual uranyl ions $\mathrm{UO}_{2}{ }^{2+}$ in the solutions after sorption.

A fluorimetric method for determination of residual uranyl ions $\mathrm{UO}_{2}{ }^{2+}$ in solutions was developed, the method being based on the fluorescence of the uranyl ion complex in a phosphate media supplemented with sodium metaphosphate.

The list of the SPEs investigated for $\mathrm{UO}_{2}{ }^{2+}$ removal is provided in Table 3.

Sorption properties of the SPEs C1119, C1140 were studied in a batch mode. Luminescence was 
measured in the range of $400-600 \mathrm{~nm}$ using a Shimadzu RF1501 spectrofluorimeter in $1 \mathrm{~cm}$ quartz cells at a $285 \mathrm{~nm}$ excitation wavelength (slit width, $10 \mathrm{~nm}$ ).

Fig. 4 shows the $\mathrm{pH}$ effect on the removal rate of uranyl ions by the SPEs C1119 and C1140.

The SPEs designed have high removal rates of uranyl ions from aqueous solutions in the wide pH range. Table 4 lists calculated sorption capacities of the SPEs C1119 and C1140 for uranyl ions.

Sorption kinetics of $\mathrm{UO}_{2}^{2+}$ ions on the materials studied, just as for the SPEs containing TODGA, is in the best agreement with a Dumwald-Wagner model.

\section{Extractive columns for europium (americium) and uranium concentration}

Extractive columns for americium concentration were manufactured based on the material C1141 (an analogue of C1103 with larger particle size permitting free liquid flow) and extractive columns for uranium concentration were manufactured based on the material C1140. Further radionuclide quantification is contemplated to perform by a radiometric assay. $1 \mathrm{~cm}^{3}$ bodies for column manufacture (Fig. 5) were purchased from Chromabond ${ }^{\circledR}$.

Sorbent volume in the column is $0.5 \mathrm{~cm}^{3}$, sorbent mass is $0.2 \mathrm{~g}$. The columns designed are being studied on real samples of spent nuclear fuel and drain waters from nuclear power stations.

\section{Conclusions}

1. The SPEs designed with the use of porous divinylbenzene polymers and styrene-divinylbenzene copolymers from Smoly SOE (Kamianske) impregnated by the chelating agent, $N, N, N^{\prime}, N^{\prime}$-tetra- $n$-octyl-oxapentane-1,5-diamide (TODGA) (40\% w/w) effectively remove $\mathrm{Eu}(\mathrm{III})$ ions from aqueous media.

2. Efficacious removal is also observed in the $\mathrm{pH}$ range of 2 to 7 , which allows using the mentioned SPEs for both reprocessing spent nuclear fuel and purifying drain waters from nuclear power stations.

3. The maximum sorption capacity of the TODGA based SPEs for Eu(III) is $25 \mathrm{mg} / \mathrm{g}$. Sorption isotherm patterns confirm chelate complex formation between the metal ion and TODGA. The polymeric matrix does not contribute to metal cation binding by the SPEs.

4. The study of the sorption behavior of the SPEs C1119 and C1140 has demonstrated that all sorbents have the $\mathrm{UO}_{2}{ }^{2+}$ removal rate above $75 \%$ in the wide $\mathrm{pH}$ range. Calculated uranyl sorption capacity of the selected sorbents is 35$39 \mathrm{mg} / \mathrm{g}$.

The study is financially supported by the National Academy of Sciences of Ukraine within the project Novel Polymeric Sorption Materials for Radioecological Monitoring, state registration no. 0119U101248.

\section{REFERENCES}

1. Dariia Ternova, Ali Ouadi, Vale'rie Mazan, Sylvia Georg, Maria Boltoeva, Vitaly Kalchenko, Stanislas Miroshnichenko, Isabelle Billard, Clotilde Gaillar. (2018). New Ionic Liquid Based on the CMPO Pattern for the Sequential Extraction of U(VI), Am(III) and Eu(III).J. Solution Chem., 47(8), 1309-1325.

2. Rashydov, N., Berezhna, V. (2009). Radiobiological Effects Of ${ }^{241}$ Am Incorporated In Cells Of Organism And Methods Of Prevention Of The Menace Of Combined Toxicity Of The Transuranium Elements. In: New Techniques for the Detection of Nuclear and Radioactive Agents. NATO Science for Peace and Security Series B: Physics and Biophysics. Eds. Aycik G.A. Dordrecht: Springer.

3. Biswajit Sadhu, Mahesh Sundararajan, and Tusar Bandyopadhyay. (2016). Efficient Separation of Europium Over Americium Using Cucurbit-[5]-uril Supramolecule: A Relativistic DFT Based Investigation. Inorg. Chem., 55(2), 598-609.

4. Salih Ozçubukçu, Kalyanaswer Mandal, Seraphine Wegner, Mark P. Jensen, and Chuan He. (2011). Selective Recognition of Americium by Peptide-Based Reagents. Inorg. Chem., 50, 7937-7939.

5. Panasyuk, M. I., Lytvyn, I. A. (2017). Regularities of Uranium distribution in groundwater of ChNPP industrial site. Nuclear Physics and Atomic Energy, 18(1), 56-62 [in Russian]. 
6. Krasnopyorova, A.P., Yukhno, G. D., Ternova, D. S., Miroshnichenko, S. I., Korovin, V. Yu., Korovin, Yu. F., Kalchenko, V. I. (2013). Uranium (VI) extraction by porous styrene-divinylbenzene co-polymer impregnated with calixarene tetraphosphineoxide. Reports of the National Academy of Sciences of Ukraine, 11, 124-129 [in Ukrainian].

7. A.s.1868237/23-5 SSSR, M.Kl.S 08f 1/84, S 08f 19/02, S 08j 1/26. Method of obtaining sorbent. A. N. Bolotov, Yu. I. Kuzovov, L. K. Kodubenko, Yu. F. Korovin, Yu. V. Trofimov.

8. Leonchini, J. Huskens, W. Verboom. (2016). Preparation of Diglycolamides via Schotten-Baumann Approach and Direct Amidation of Esters. Synlett., 27(17), 2463-2466.

9. Horwitz, E. P., Kalina, D. G., Diamond, H., Vandegriff, G. F., Schulz, E. P. (1985). The TRUEX Process - a Process for the Extraction Transuranic Elements from Nitric AC In Wastes Utilizing Modified PUREX Solvent. Solv. Extr. Ion Exch., $3,15-23$.

10. Wen Zhang, Xihong He, Gang Ye, Rong Yi and Jing Chen. (2014). Americium(III) Capture Using Phosphonic AcidFunctionalized Silicas with Different Mesoporous Morphologies: Adsorption Behavior Study and Mechanism Investigation by EXAFS/XPS. Environ. Sci. Technol., 48, 6874-6881.

11. Maloubier, M., Shuh, D. K., Minasian, S. G., Pacold, J., Solari, P. L., Michel, H., Oberhaensli, F. R., Bottein, Y., Monfort, M., Moulin, C., Den Auwer, C. (2016). How Do Radionuclides Accumulate in Marine Organisms. A Case Study of Europium with Aplysina cavernicola. Environ Sci Technol., 50(19), 10730-10738.

12. Bell, K., Geist, A., McLachlan, F., Modolo, G., Taylor, R., Wilden, A. (2012). Nitric Acid Extraction into TODGA. Procedia Chem., 7, 152-159.

13. Lujanienè, G., Melesherych, S., Kanibolotskyy, V., Šapolaitè,J., Strelko, V., Remeikis, V., Oleksienko, O., Ribokaitè, K., Ščiglo, T. (2009). Application of inorganic sorbents for removal of Cs, Sr, Pu and Am from contaminated solutions. J. Radioanal. Nucl. Chem., 282, 787-791.

Received 01.12.2020

Revised 12.12.2020

Accepted 02.02.2021

К.М. Бєліков ${ }^{1}$ (https://orcid.org/0000-0002-1682-6064),

К.Ю. Брильова ${ }^{1}$ (https://orcid.org/0000-0002-8903-4922),

3.Ю. Буніна ${ }^{1}$ (https://orcid.org/0000-0002-8639-958X),

В.В. Варченко ${ }^{1}$ (https://orcid.org/0000-0002-7369-1637),

Г.Ю. Андрющенко ${ }^{1}$ (https://orcid.org/0000-0001-6256-2568)

I.Б.-Х. Щербаков ${ }^{1}$ (https://orcid.org/0000-0002-9450-2153),

B.I. Кальченко ${ }^{1}$ (https://orcid.org/0000-0002-0325-7544),

А.Б. Драпайло ${ }^{1}$ (https://orcid.org/0000-0002-8701-1380),

О.В. Зонтов ${ }^{1}$ (https://orcid.org/0000-0003-0520-5833),

Л.В. Зонтова ${ }^{1}$ (https://orcid.org/0000-0002-3361-2535)

${ }^{1}$ Державна наукова установа «НТК «Інститут монокристалів» НАНУ, просп. Науки, 60, Харків, 61072, Україна,

+380573410357,info@isc.kh.ua

${ }^{2}$ Інститут органічної хімії НАНУ, вул. Мурманська, 5, Київ, 02660, Україна, +380 44292 7150, ioch@ioch.kiev.ua

${ }^{3}$ Державне підприємство «СМОЛИ», просп. Аношкіна, 179, Кам'янське, 51917, Дніпропетровська обл., Україна,

+38056958 4523, dpsmoly@gmail.com

ТВЕРДІ ЕКСТРАГЕНТИ ДЛЯ ВИЛУЧЕННЯ

АКТИНІДІВ ТА ЛАНТАНІДІВ НА ОСНОВІ ПОРУВАТИХ

ПОЛІМЕРІВ, ІМПРЕГНОВАНИХ ПОЛІДЕНТАТНИМИ

ХЕЛАТУЮЧИМИ ЛІГАНДАМИ

Вступ. Переробка та утилізація радіоактивних відходів, а також контроль вмісту радіоактивних ізотопів в об'єктах навколишнього середовища $є$ актуальною задачею для розвинених країн світу. Вилучення лантанідів та трансурано- 
вих елементів з відпрацьованого ядерного палива атомних електростанцій дозволить зменшити кількість відходів, що підлягають захороненню, та знизити ризик забруднення радіонуклідами навколишнього середовища.

Проблематика. 3 огляду на екстремальну радіотоксичність трансуранових елементів та жорсткі норми, що регламентують їхню активність у повітрі та воді, існує нагальна потреба у розвитку точних та високочутливих методів контролю стану забруднення об’єктів навколишнього середовища.

Мета. Створення твердих екстрагентів (ТВЕКСів) на основі поруватих полімерів, імпрегнованих полідентатними хелатуючими комплексоутворювачами, для вилучення лантанідів, урану і трансуранових елементів з водних розчинів.

Матеріали й методи. Поруваті полімери дивінілбензену марки ПОРОЛАС та кополімери стирену та дивінілбензену виробництва ДП «СМОЛИ» (м. Кам'янське); полідентатні хелатуючі комплексоутворювачі актинідів та лантанідів $\mathrm{N}, \mathrm{N}, \mathrm{N}^{\prime}, \mathrm{N}^{\prime}$-тетра-н-октил-оксапентан-1,5-диамід (ТОДГА) та карбамоїлфосфіноксиди (КМФО); сорбент компанії TRISKEM (Франція) на основі матеріалу TRU Resin (Eichrom Industries, Inc.). Методи дослідження - атомно-емісійна спектрометрія з індуктивно-зв'язаною плазмою, ІЧ-спектроскопія, скануюча електронна спектроскопія, спектрофлуориметрія.

Результати. Імпрегнуванням поруватих полімерних матриць лігандами ТОДГА та КМФО отримано ТВЕКСи для вилучення урану та європію з водних розчинів. Визначено сорбційні характеристики отриманих матеріалів та на їх основі виготовлено екстракційні колонки.

Висновки. Досліджені ТВЕКСи демонструють високу ефективність при вилученні урану та європію з водного середовища. Характеристики отриманих матеріалів дозволяють використовувати їх для попереднього концентрування цільових іонів в методиках радіоекологічного моніторингу

Ключові слова: сорбент, твекс, карбамоїлметилфосфіноксиди, тетраоктилдіамід дигліколевої кислоти, радіонукліди. 